\title{
Pertanggungjawaban Pidana Korporasi dalam Pelanggaran Hak Asasi Manusia yang Berat
}

\author{
Mahrus Ali \\ Fakultas Hukum Universitas Islam Indonesia Yogyakarta \\ Jl. Tamansiswa No. 158 Yogyakarta \\ surham_02@yahoo.com
}

\begin{abstract}
This research focuses on corporate criminal liability for gross violation of human rights. Based on normative legal research, this research reveals; first, extending criminal responsibility beyond individual to corporation for gross violation of human rights is required because national states are sometimes unwilling or powerless to properly sanction corporations for fear of negative economic consequences. Corporation also results serious or systematic human rights violations and encourages criminal conduct by maintaining a corporate culture that condones or even rewards violations of the law; second, Canada and Australia have opened a prosecutorial window by suing Unocal and Anvil Mining Limited as the perpetrator of crime against humanity; last, In Indonesia prosecuting corporation for human right violations will resulted into reformulation of criminal conduct of abetting, limitation of corporate responsibility and punishment and treatment.
\end{abstract}

Key words : Corporation, criminal responsibility, gross violation of buman rights.

\begin{abstract}
Abstrak
Penelitian ini difokuskan pada persoalan pertanggungjawaban pidana korporasi dalam pelanggaran HAM yang berat. Dengan menggunakan metode penelitian hukum normatif, penelitian ini menyimpulkan; pertama, pertanggungjawaban pidana korporasi dalam pelanggaran HAM yang berat diperlukan selain karena seringkali negara-negara tidak bersedia dan tidak memiliki kekuatan untuk memidana korporasi dengan alasan takut menanggung konsekuensi ekonomis yang bersifat negatif, juga karena korporasi terbukti dapat melakukan pelanggaran HAM yang berat yang menimbulkan efek negatif yang luar biasa, berkepanjangan dan sistematik, serta pemeliharaan budaya kerja untuk melakukan pelanggaran tersebut; kedua, dalam perkara pelanggaran HAM yang berat Kanada dan Australia mengakui korporasi sebagai subjek delik, terbukti dari dijadikannya perusahaan Unocal dan Anvil sebagai pelaku dalam kejahatan terhadap kemanusiaan; ketiga, di Indonesia pengakuan korporasi sebagai subjek delik dalam pelanggaran HAM yang berat akan berimplikasi pada formulasi tindak pidana penyertaan, ketentuan limitatif pihak yang bertanggungjawab dan bentuk-bentuk sanksi pidana dan tindakan.
\end{abstract}

Kata kunci : Korporasi, pertanggungjawaban pidana, pelanggaran HAM yang berat. 


\section{Pendahuluan}

Dewasa ini korporasi memiliki peranan yang sangat penting terhadap pertumbuhan ekonomi suatu negara, seperti meningkatkan penerimaan pajak dan standar hidup masyarakat, menciptakan lapangan pekerjaan, serta berkontribusi positif terhadap pertumbuhan suatu negara. Bahkan, dalam beberapa aspek peranan korporasi melebihi peranan dan pengaruh suatu negara. ${ }^{1}$ Dari tahun ke tahun, kuantitas korporasi terutama korporasi multinasional (Multi National Corporation) mengalami peningkatan yang luar biasa. Bila 1999 jumlah MNC induk sebanyak 60.000 dengan MNC cabang yang tersebar di banyak negara sebanyak 500.000, ${ }^{2} 2005$ jumlah tersebut meningkat drastis, yakni sebanyak 77.000 MNC induk dan 770.000 MNC cabang. ${ }^{3}$ Tidak mengherankan apabila antara 29 sampai 51 \% perekonomian dunia dikuasi oleh korporasi tersebut. ${ }^{4}$

Namun demikian, peranan penting dan positif korporasi terhadap pertumbuhan ekonomi suatu negara seringkali diikuti oleh pelanggaran-pelanggaran yang mengarah pada hukum pidana. Tidak jarang korporasi melakukan unfair business yang tidak hanya merugikan suatu negara dan konsumen, tapi juga dapat dikategorikan sebagai tindak pidana. Ketika korporasi melakukan tindak pidana, maka ia dapat dipertanggungjawabkan atas tindak pidana yang dilakukan baik ditujuukan kepada pengurusnya maupun ditujukan langsung kepada korporasi. Pengakuan korporasi sebagai subjek delik dalam hukum pidana bukan merupakan hal baru dan tidak menimbulkan persoalan hukum yang berarti.

Permasalahan baru muncul manakala korporasi melakukan tindak pidana yang dikategorikan sebagai pelanggaran Hak Asasi Manusia (HAM) yang berat, seperti kejahatan terhadap kemanusiaan, genosida, dan kejahatan perang. Hal ini karena baik Statuta Roma maupun Undang-Undang No. 26 Tahun 2000 tentang Pengadilan HAM tidak mengakui korporasi sebagai subjek delik. Kedua instrumen hukum tersebut hanya mengenal pertanggungjawaban pidana individu (individual criminal responsibility) bukan pertanggungjawaban pidana korporasi (corporate criminal responsibility).

\footnotetext{
${ }^{1}$ Cf. Henry J. Steiner, "Organizational Irrationality and Corporate Human Rights Violations”, Harvard Law Review, 2009, hlm. 1931.

${ }^{2}$ Phillip I. Blumberg, "Asserting Human Rights Against Multinational Corporations Under United States Law: Conceptual and Procedural Problems”, American Journal of Comparative Law, 2002, hlm. 493.

${ }^{3}$ Jonathan Clough, "Punishing the Parent: Corporate Criminal Complicity In Human Rights Abuses" Brooklyn Journal of International Law, 2008, hlm. 899.

${ }^{4}$ Ibid.
} 


\section{Rumusan Masalah}

Berdasarkan permasalahan hukum yang timbul berkaitan dengan tindak pidana yang dilakukan korporasi yang dapat dikategorikan sebagai pelanggaran HAM yang berat, maka rumusan masalah dalam penelitian ini adalah; alasan-alasan apa saja yang dapat dijadikan dasar bahwa korporasi dapat dipertanggungjawabkan secara pidana atas pelanggaran HAM yang berat? Bagaimana pengaturan dan penerapan pertanggungjawaban korporasi dalam pelanggaran HAM yang berat di Kanada dan Australia? Apa implikasi hukum terkait formulasi tindak pidana, pertanggungjawaban pidana dan sanksi pidana bilamana korporasi dipertanggungjawabkan atas pelanggaran HAM yang berat di Indonesia?

\section{Tujuan Penelitian}

Penelitian ini bertujuan untuk mengetahui, menjelaskan dan menganalisis alasan perlunya korporasi dipertanggungjawabkan secara pidana atas pelanggaran HAM yang berat; pengaturan pertanggungjawaban korporasi dan penerapannya dalam perkara pelanggaran HAM yang berat di Kanada dan Australia; dan implikasi hukum yang muncul bila korporasi dipertanggungjawabkan secara pidana atas pelanggaran HAM yang berat di Indonesia.

\section{Metode Penelitian}

Penelitian ini merupakan penelitian hukum normatif/doktrinal yang mengkaji kaidah perundang-undangan dan perkara pelanggaran HAM yang berat oleh korporasi. ${ }^{5}$ Bahan hukum yang digunakan adalah bahan hukum primer, bahan hukum sekunder, dan bahan tersier. Sedangkan pendekatan yang digunakan adalah pendekatan perundang-undangan (statute approach), pendekatan konsep (conseptual approach), pendekatan perbandingan (comparative approach), dan pendekatan kasus (case approach). ${ }^{6}$

Bahan hukum dikumpulkan dengan dua cara, yaitu studi dokumen dan studi literatur terkait dengan keberadaan korporasi dalam pelanggaran HAM yang berat.

\footnotetext{
hlm. 147-176.

${ }^{5}$ Lihat Soetandyo Wigjnosoebroto, Hukum, Paradigma, Metode dan Dinamika Masalabnya, HuMa, Jakarta, 2002,

${ }^{6}$ Uraian tentang pendekatan dalam penelitian hukum normatif, lihat Peter Mahmud Marzuki, Penelitian Hukum, Cetk. Kedua, Prenada Media, Jakarta, 2006.
} 
Adapun temuan hasil penelitian yang diperoleh dari ketiga bahan di atas selanjutnya dianalisis secara deskriptif kualitatif melalui tiga alur kegiatan, yakni reduksi bahan hukum, penyajian bahan hukum dan penarikan kesimpulan. ${ }^{7}$

\section{Hasil Penelitian dan Pembahasan}

\section{Alasan Pertanggungjawaban Korporasi dalam Pelanggaran HAM yang Berat}

Dikaji dari aspek historis, pengakuan korporasi sebagai subjek delik dalam hukum pidana sudah berlangsung sejak 1635 ketika sistem hukum Inggris mengakui bahwa korporasi dapat bertanggungjawab secara pidana atas tindak pidana ringan. ${ }^{8}$ Amerika baru mengakui eksistensinya pada 1909 melalui putusan pengadilan. ${ }^{9}$ Setelah itu, Belanda, Italia, Perancis, Kanada, Australia, Swiss, dan beberapa negara Eropa mengikuti trend tersebut, termasuk Indonesia. ${ }^{10}$

Pertanggungjawaban korporasi dalam hukum pidana muncul tidak melalui penelitian yang mendalam para ahli, tapi sebagai akibat dari kecenderungan dari formalisme hukum (legal formalism). Doktrin pertanggungjawaban pidana korporasi telah berkembang melalui peran pengadilan tanpa adanya teori yang membenarkannya. Hakim di dalam sistem common law melakukan suatu analogi atas subjek hukum manusia, sehingga korporasi juga memiliki identitas hukum dan penguasaan kekayaan dari pengurus yang menciptakannya. ${ }^{11}$

Para hakim yang pada waktu itu tidak memiliki banyak teori untuk membebankan tindakan para agen kepada korporasi, berusaha dengan suatu pertanyaan apakah suatu korporasi, dengan entitas hukum tanpa memiliki bentuk psikis yang jelas, dapat juga dipersyaratkan memiliki tindakan psikologis untuk

\footnotetext{
${ }^{7}$ Matthew B. Miles dan A. Michael Huberman, Analisis Data Kualitatif, tanpa Penerbit, tt, hlm. 20.

${ }^{8}$ Andrew Weissmann dan David Newman, "Rethinking Criminal Corporate Liability", Indiana Law Journal, 2007, hlm. 419.

${ }^{9}$ Leonard Orland, "The Transformation of Corporate Criminal Law", Brooklyn Journal of Corporate, Finansial \& Commercial Law, 2006, hlm 46; Zachary Bookman, "Convergences And Omissions In Reporting Corporate And White Collar Crime, DePaul Business \& Commercial Law Journal, 2008, hlm. 347.

${ }^{10} \mathrm{Di}$ Indonesia pengakuan korporasi sebagai subjek delik sehingga dapat dipertanggungjawabkan atas tindak pidana yang dilakukan terdapat dalam peraturan perundang-undangan pidana di luar KUHP, yakni pertama kali dalam UU No 7 Drt tahun 1955 tentang Tindak Pidana Ekonomi, dan terus berlanjut hingga saat ini. Dalam KUHP suatu delik hanya dapat dilakukan oleh manusia, sedangkan badan hukum (rechts persoon) tidak diakui. Hamzah Hatrik, Asas Pertanggunggjawaban Korporasi Dalam Hukum Pidana (Strick Liability dan Vicarious Liability), PT Raja Grafindo Persada, Jakarta, 1996, hlm. 30.

${ }^{11}$ Andrew Weissmaan dan David Newman, "Rethingking Criminal Corporate Liability", Indiana Law Journal, Vol. 82, No. 411, 2007, hlm. 418-419.
} 
adanya suatu penuntutan sebagaimana halnya kejahatan-kejahatan lain yang mensyaratkan adanya hal itu. ${ }^{12}$ Berdasarkan pemikiran ini, akhirnya "disepakati" bahwa korporasi juga dianggap sebagai subjek hukum yang bertanggung jawab hanya pada kejahatan-kejahatan ringan. Konsep ini bertahan hingga akhir abad ke-19.13

Baru kemudian, ahli mencari dasar pembenar perlunya korporasi dipertanggungjawabkan dalam hukum pidana. Pertama, korporasi merupakan aktor utama dalam perekonomian dunia, sehingga kehadiran hukum pidana dianggap sebagai metode yang paling efektif untuk mempengaruhi tindakan-tindakan aktor rasional korporasi. ${ }^{14}$ Kedua, keuntungan yang diperoleh korporasi dan kerugian yang diderita masyarakat dapat demikian besarnya, sehingga tidak akan mungkin seimbang bilamana korporasi hanya dijatuhi sanksi keperdataan. ${ }^{15}$ Tindakan korporasi melalui agen-agennya pada satu sisi seringkali menimbulkan kerugian yang sangat besar di masyarakat, sehingga kehadiran sanksi pidana diharapkan mampu mencegahnya dari mengulangi tindakannya itu. ${ }^{16}$

Umumnya, pertanggungjawaban korporasi didasarkan pada doktrin respondeat superior, suatu doktrin yang menyatakan bahwa korporasi sendiri tidak bisa melakukan kesalahan. Hanya agen-agen yang bertindak untuk dan atas nama korporasi saja yang dapat melakukan kesalahan. Oleh karenanya, pertanggung jawaban korporasi merupakan suatu bentuk pertanggung jawaban atas tindakan orang lain/agen (vicarious liability), di mana ia bertanggung jawab atas kesalahan yang dilakukan oleh para agen. Doktrin ini diambil dari hukum perdata yang diterapkan pada hukum pidana. Vicarious liability biasanya berlaku dalam hukum perdata tentang perbuatan melawan hukum berdasarkan doktrin respondeat superior. ${ }^{17}$ Ada tiga syarat yang harus dipenuhi untuk adanya pertanggung jawaban korporasi, yaitu; agen melakukan suatu kejahatan; kejahatan yang dilakukan itu masih dalam ruang lingkup pekerjaannya; dan dilakukan dengan tujuan untuk menguntungkan korporasi. ${ }^{18}$

${ }^{12}$ Yedidia Z. Stern, “Corporate Criminal Personal Liability - Who Is The Corporation?”, Journal of Corporation Law, 1987, hlm. 125.

${ }^{13}$ Ibid., hlm. 420.

${ }^{14}$ Pamela H. Bucy, "Trends In Corporate Criminal Prosecutions”, American Criminal Law Review, 2007, hlm. 1288

${ }^{15}$ Beth Stephens, "The Amorality of Profit: Transnational Corporations and Human Rights", Berkeley Journal of International Law, 2002, hlm. 46; Dwidja Priyanto, Kebijakan Legislatif Tentang Sistem Pertanggungjawaban Korporasi di Indonesia, CV. Utomo, Bandung, 2004, hlm. 27-28; Mahrus Ali, Kejahatan Korporasi, Arti Bumi Intaran, Yogyakarta, 2008.

${ }^{16}$ Geraldine Szott Moohr, “On The Prospects Of Deterring Corporate Crime”, Journal of Business \& Technology Law, 2007, hlm. 27.

${ }^{17}$ Sutan Remy Sjahdeini, Pertanggung Jawaban Pidana Korporasi, Grafiti Pers, Jakarta, 2006, hlm. 84.

${ }^{18}$ V.S. Khanna, “Corporate Liability Standars: When Should Corporation Be Criminality Liabel?”, American Criminal Law Review, 2000, hlm. 1242-1243. 
Doktrin respondeat superior menghasilkan tiga model pertanggungjawaban pidana korporasi, yaitu direct corporate criminal liability, strict liability, dan vicarious liability. Dalam Direct corporate criminal liability (pertangungjawaban korporasi secara langsung), korporasi bisa melakukan sejumlah delik secara langsung melalui para agen yang sangat berhubungan erat dengan korporasi, bertindak untuk dan atau atas nama korporasi. Syarat adanya pertanggungjawaban pidana korporasi secara langsung adalah tindakan-tindakan para agen tersebut masih dalam ruang lingkup pekerjaan korporasi. ${ }^{19}$ Direct corporate criminal liability berhubungan erat dengan doktrin identifikasi, yang menyatakan bahwa pada dasarnya mengakui bahwa tindakan dari agen tertentu dari korporasi, selama tindakan itu berkaitan dengan korporasi, dianggap sebagai tindakan dari korporasi itu sendiri. ${ }^{20}$

Strict liability diartikan sebagai suatu perbuatan pidana dengan tidak mensyaratkan adanya kesalahan pada diri pelaku terhadap satu atau lebih dari actus reus. ${ }^{21}$ Strict liability ini merupakan pertanggungjawaban tanpa kesalahan (liability without fault). Dapat ditegaskan bahwa dalam perbuatan pidana yang bersifat strict liability hanya dibutuhkan dugaan atau pengetahuan dari pelaku (terdakwa), sudah cukup menuntut pertanggungjawaban pidana dari padanya. Jadi, tidak dipersoalkan adanya mens rea karena unsur pokok strict liability adalah actus reus (perbuatan) sehingga yang harus dibuktikan adalah actus reus (perbuatan), bukan mens rea (kesalahan). ${ }^{22}$

Vicarious liability (pertanggungjawaban pengganti) diartikan sebagai pertanggungjawaban menurut hukum seseorang atas perbuatan salah yang dilakukan oleh orang lain. ${ }^{23}$ Teori ini juga hanya dibatasi pada keadaan tertentu di mana majikan (korporasi) hanya bertangungjawab atas perbuatan salah pekerja yang masih dalam ruang lingkup pekerjaannya. ${ }^{24}$ Rasionalitas penerapan teori ini adalah karena majikan (korporasi) memiliki kontrol dan kekuasaan atas mereka dan keuntungan yang mereka peroleh secara langsung dimiliki oleh majikan (korporasi). ${ }^{25}$

\footnotetext{
${ }^{19}$ Sue Titus Reid, Criminal Law, Third Edition, Prentice Hall, New Jersey, 1995, hlm 53; Wayne R LaFave \& Austin W. Scott Jr, Criminal Law, West Publishing co, 1982, hlm. 228.

${ }^{20}$ Eric Colvin, "Corporate Personality And Criminal Liability”, Criminal Law Forum, 1995, hlm. 8-9.

${ }^{21}$ Russel Heaton, Criminal Law Textbook, Oxford University Press, London, 2006, hlm. 403.

${ }^{22}$ Hanafi, Strict Liability dan Vicarious Liability dalam Hukum Pidana, Lembaga Penelitian, Universitas Islam Indonesia, Yogyakarta, 1997, hlm. 63-64.

${ }^{23}$ Sue Titur Reid, Op. Cit., hlm. 53.

${ }^{24}$ C.M.V. Clarkson, Understanding Criminal Law,Second Edition, Sweet \& Maxwell, London, 1998, hlm. 44

${ }^{25}$ Ibid., hlm. 45.
} 
Prinsip hubungan kerja dalam vicarious liability disebut dengan prinsip delegasi, yakni berkaitan dengan pemberian izin kepada seseorang untuk mengelola suatu usaha. Pemegang izin tidak menjalankan langsung usaha tersebut, akan tetapi ia memberikan kepercayaan (mendelegasikan) secara penuh kepada seorang manager untuk mengelola korporasi tersebut. Jika manager itu melakukan perbuatan melawan hukum, maka pemegang izin (pemberi delegasi) bertanggungjawab atas perbuatan manager itu.

Ketika korporasi dinyatakan bertanggungjawaban secara pidana atas tindak pidana yang dilakukan, maka dikenal tiga sistem pertanggungjawaban korporasi; yaitu, pengurus korporasi sebagai pembuat, penguruslah yang bertanggungjawab, korporasi sebagai pembuat, pengurus yang bertanggungjawab, dan korporasi sebagai pembuat dan yang bertanggungjawab. ${ }^{26}$

Dalam konteks pelanggaran HAM yang berat, korporasi tidak diakui sebagai subjek delik. Baik Statuta Roma maupun UU pengadilan HAM hanya mengakui individu sebagai subjek hukum dalam kejahatan HAM yang berat. Ketika terjadi perkara pelanggaran HAM yang berat, maka Mahkamah Pidana Internasional (International Criminal Court) atau Pengadilan HAM hanya berwenang mengadili perkara tersebut bila pelakunya adalah individu, bukan korporasi atau negara. Sebab, Statuta Roma atau Pengadilan HAM hanya mengenal pertanggungjawaban pidana individu (individual criminal responsibility).

Walaupun Statuta Roma secara eksplisit hanya mengakui pertanggungjawaban pidana individu, yang menarik adalah ternyata beberapa negara mengakui eksistensi korporasi sebagai subjek delik dalam pelanggaran HAM yang berat dan menerapkannya dalam kasus-kasus yang melibatkan korporasi. Paling tidak terdapat empat alasan yang dikemukan dalam hubungan ini. Pertama, perluasan subjek delik yang meliputi korporasi multinasional (MNC) akan berguna, karena kadangkala negara-negara tempat di mana korporasi melakukan pelanggaran HAM yang berat tidak bersedia atau tidak memiliki kekuatan untuk menjatuhkan sanksi pidana kepada korporasi disebabkan adanya rasa takut negara tersebut akan menanggung konsekuensi ekonomi yang bersifat negatif. Kedua, dewasa ini peranan korporasi multinasional (MNC) untuk melakukan kejahatan-kejahatan bisnis dan lingkungan hidup dalam skala yang besar seringkali terjadi dan kadangkala menimbulkan efek

${ }^{26}$ Mardjono Reksodiputro, 'Pertanggungjawaban Pidana Korporasi Dalam Tindak Pidana Korporasi”, makalah disampaikan pada Seminar Nasional Kejahatan Korporasi, FH UNDIP, Semarang, 23-24 Novemser 1989, hlm. 9. 
negatif yang berkepanjangan dan luar biasa. Ketiga, tidak sedikit korporasi yang memiliki "kebiasaan" melakukan tindak pidana dengan memelihara budaya korporasi yang memungkinkan terjadinya perbuatan-perbuatan yang dilarang. ${ }^{27}$ Artinya, korporasi "memaksa" agen-agen agar terbiasa melakukan tindak pidana termasuk pelanggaran HAM yang berat, dengan tujuan agar keuntungan finansial yang diperoleh dalam jumlah yang besar dengan risiko yang kecil.

Keempat, dalam beberapa kasus seringkali korporasi terlibat langsung dalam pelanggaran HAM yang berat yang serius dan sistemasik, seperti pembunuhan, penyiksaan, penangkapan secara tidak sah, kerja paksa, bentuk-bentuk lain eksploitasi anak, pelanggaran HAM yang berat terhadap individu dalam situasi perang dan konflik, kerusakan yang sangat parah terhadap lingkungan hidup. Salah satu contoh dari kasus tersebut adalah yang dilakukan oleh Militer Myanmar. ${ }^{28}$

Empat alasan tersebut yang dijadikan dasar untuk memasukkan korporasi sebagai pihak yang dapat melakukan pelanggaran HAM yang berat. Oleh karena itu, beberapa negara seperti Kanada, Australia, Belanda, dan Inggris secara eksplisit menjadikan korporasi sebagai subjek delik dalam perundang-undangan pidana mereka terkait pelanggaran HAM yang berat. Negara-negara tersebut memperluas subjek delik dalam Statuta Roma yang tidak hanya pada manusia tapi juga pada korporasi dalam pelanggaran HAM yang berat.

\section{Pertanggungjawaban Korporasi dalam Pelanggaran HAM Berat di Kanada dan}

\section{Australia}

Kanada membentuk undang-undang tentang kejahatan terhadap kemanusiaan dan kejahatan perang (The Canadian Crimes Against Humanity and War Crimes Act) 2000, di mana salah satu isinya adalah memperluas cakupan makna "setiap orang" yang tidak hanya individu melainkan juga korporasi. Korporasi dapat dipidana atas tindak pidana membantu dan bekerjasama (penyertaan) untuk melakukan kejahatan terhadap kemanusiaan dan kejahatan perang. Pengertian "membantu" dan bekerjasama" terdapat dalam Pasal 21 KUHP Kanada, yaitu setiap orang yang

${ }^{27}$ Thomas Weigend, “Societas Delinquere Non Potest? A German Perspective”, Journal of International Criminal Justice, 2008, hlm. 929-933.

${ }^{28}$ Andrew Clapham, "Extending International Criminal Law beyond the Individual to Corporations and Armed Opposition Groups", Journal of International Criminal Justice, 2008, hlm 903; Gregory G.A. Tzeutschler, "Corporate Violator: the Alien Tort Liability of Transnational Corporations for Human Rights Abuses Abroad”, Columbia Human Rights Law Review, 1999, hlm. 409-422. 
(1) melakukan tindak pidana (2) mengabaikan kewajiban yang seharusnya dilakukan dengan tujuan membantu orang lain melakukan tindak pidana, atau (3) bekerjasama dengan orang lain melakukan tindak pidana. ${ }^{29}$

Agar ketentuan Pasal 21 terbukti, maka harus dipenuhi dua unsur, yaitu unsur perbuatan pidana (criminal act/actur reus) dan kesalahan (criminal responsibility/mens rea). Dalam konteks ini, suatu korporasi dianggap terbukti melakukan kejahatan terhadap kemanusiaan dan kejahatan perang berupa "membantu" bila korporasi memberikan bantuan, apapun bentuknya, dalam terjadinya dua kejahatan dimaksud. Makna "bekerjasama" meliputi menyuruh, menghasut, menganjurkan, atau menyediakan sarana untuk melakukan tindak pidana. ${ }^{30}$

Adapun unsur kesalahan tidak diberikan arti yang eksplisit dalam Pasal 21, hanya saja terdakwa dianggap memiliki kesalahan bila ia secara sadar atau sengaja membiarkan fakta bahwa tindakannya itu merupakan kejahatan terjadap perang dan kejahatan terhadap kemanusiaan, termasuk apabila tindakannya itu merupakan bagian dari serangan yang meluas atau sistematik yang ditujukan kepada penduduk sipil. Dalam hubungan ini, bila korporasi tahu atau sadar bahwa tindakannya itu masuk dalam kategori membantu atau bekerjasama melakukan kejahatan perang atau kejahatan terhadap kemanusiaan yang dilakukan orang lain, maka korporasi dianggap memiliki kesalahan. ${ }^{31}$

Selain itu, yang menarik dari undang-undang tentang kejahatan terhadap kemanusiaan dan kejahatan perang adalah bahwa undang-undang diberlakukan secara surut (asas retroaktif) terhadap kejahatan terhadap kemanusiaan, kejahatan perang dan genosida yang terjadi sebelum undang-undang ini dibentuk. Ketentuan ini jelas berbeda dengan Statuta Roma yang membatasi jurisdiksinya pada pelanggaran HAM berat yang terjadi setelah 1 Juli 2002. ${ }^{32}$

Contoh keterlibatan korporasi dalam pelanggaran HAM yang berat dapat dilihat pada kasus Unocal, Total dan pemerintahan Junta Myanmar yang melakukan kerjasama joint venture dalam pembuatan saluran pipa gar (gas pipeline) dari laut Andaman ke Thailand yang melintasi wilayah Myanmar. Baik perusahaan Total maupun Unocal bekerjasama dengan militer Myanmar untuk mengamankan saluran pipa dan

${ }^{29}$ W. Cory Wanless, “Corporate Liability For International Crimes Under Canada’s Crimes Against Humanity And War Crimes Act”, Journal of International Criminal Justice, 2009, hlm. 207.

${ }^{30}$ Ibid.

${ }^{31}$ Ibid., hlm. 208.

${ }^{32}$ Ibid., hlm. 210. 
membangun jalan dan tempat landas helikopter sepanjang rute saluran pipa, walaupun kedua perusahaan tersebut sebenarnya mengetahui bahwa militer Myanmar merupakan salah satu militer terkejam di dunia. Akibat kerjasama tersebut, militer Myanmar melakukan pelanggaran serius berupa kerja paksa, pembunuhan, perkosaan dan penyiksaan agar proyek saluran pipa dapat diselesaikan sesuai dengan waktu yang ditentukan dalam kerjasama. ${ }^{33}$

Terkait dengan hal di atas, apakah undang-undang tentang kejahatan terhadap kemanusiaan dan kejahatan perang dapat diterapkan pada kasus tersebut? Sebab, berdasarkan ketentuan Pasal 22.2 KUHP Kanada bahwa suatu korporasi akan bertanggungjawab secara pidana atas tindak pidana yang dilakukan oleh agennya bila pejabat senior mengetahui bahwa agen tersebut melakukan tindak pidana tapi tidak mengambil tindakan yang layak untuk mencegah agar tindak pidana tersebut tidak terjadi. Tindak pidana di sini adalah terkait dengan kejahatan terhadap kemanusiaan.

Terdapat empat hal yang harus dibuktikan oleh jaksa apakah Unocal melakukan kejahatan terhadap kemanusiaan, yaitu; kejahatan wakil Unocal merupakan bagian dari serangan yang meluas atau sistematik yang ditujukan kepada penduduk sipil; pejabat senior Unocal mengetahui kejahatan tersebut; kejahatan tersebut mendatangkan keuntungan finansial kepada Unocal; dan pejabat senior mengetahui terjadinya kejahatan tapi tidak mengambil tindakan yang layak untuk mencegahnya.

Berdasarkan fakta hukum di persidangan, apa yang dilakukan Unocal dapat dikategorikan sebagai kejahatan terhadap kemanusiaan..$^{34}$ Pertama, militer Myanmar dapat dianggap sebagai kontraktor yang disewa untuk pekerjaan tertentu untuk kepentingan korporasi, yakni mengamankan dan membangun jalan dan tempat landas helikopter, sehingga dalam konteks ini dapat dikategorikan sebagai wakil Unocal. Bukti hukum lain menunjukkan bahwa militer Myanmar sebagai wakil Unocal terbukti melakukan kejahatan berupa kerja paksa yang merupakan bagian dari serangan yang meluas atau sistematik yang ditujukan kepada penduduk sipil dalam kaitannya dengan proyek saluran pipa. Tindakan ini secara eksplisit

${ }^{33}$ Shanaira UdwadiaHYPERLINK "http://web2.westlaw.com/Find/Default.wl?DB=PROFILER\% 2DWLD $\&$ DocName $=0360606001 \&$ Find Type $=\mathrm{h} \& A \mathrm{P}=\& \mathrm{mlac}=\mathrm{FY} \& \mathrm{rs}=$ WLW9.10\&ifm $=$ NotSet $\& \mathrm{fn}$ $=\_$top\&sv $=$Split\&mt $=$WorldJournals\&utid=2\&vr=2.0\&pbc=942BB175" "Corporate Responsibility for International Human Rights Violations", Southern California Interdisciplinary Law Journal, 2004, hlm 359-361; Jonathan Clough, Punishing the Parent..., Op. Cit., hlm. 900-901.

${ }^{34}$ W. Cory Wanless, Op. Cit., hlm. 212-214. 
melanggar Pasal 6 (1) b undang-undang tentang kejahatan terhadap kemanusiaan dan kejahatan perang Kanada.

Kedua, Unocal terbukti mengetahui kerja paksa yang dilakukan militer Myanmar serta merupakan bagian dari serangan yang meluas atau sistematik. Dalam kasus ini, ohn Imle, Presiden Unocal, Stephen Lipman, wakil Presiden Unocal bidang eksternal dan Joel Robinson, salah satu agen Unocal sebenarnya memiliki pengetahuan tentang risiko dari kerja paksa sehingga memenuhi kriteria sebagai pejabat senior.

Ketiga, pembangunan jalan, tempat landas helikopter dan saluran pipa dengan menggunakan kerja paksa secara spesifik mendatangkan keuntungan finansial bagi Unocal. Karena dengan itu, pejabat eksekutif Unocal dapat meninjau secara langsung proyek pembangunan saluran pipa gas, sehingga dalam konteks ini Unocal mendapatkan keuntungan finansial dari proyek ini. Keempat, di persidangan juga terbukti bahwa Unocal sama sekali tidak mengambil tindakan yang layak untuk mencegah agar kerja paksa tidak terjadi. Bahkan Unocal sendiri mempengaruhi Militer Myanmar untuk menggunakan kerja paksa untuk mempercepat pelaksanaan proyek pembuatan saluran pipa gas.

Australia juga mengakui korporasi sebagai subjek delik dalam pelanggaran HAM yang berat setelah negara itu meratifikasi Statuta Roma. Walaupun Statuta Roma sendiri tidak mengakui korporasi sebagai subjek delik, tetapi ketentuan Pasal 268 secara eksplisit menyatakan bahwa KUHP Australia mengakui korporasi sebagai subjek di samping manusia, sehingga ketika suatu instrumen internasional diratifikasi oleh Australia, ketentuan dalam KUHP Australia berlaku terhadapnya. Ini artinya, subjek delik terhadap kejahatan terhadap kemanusiaan, kejahatan perang, dan genosida adalah manusia dan korporasi. ${ }^{35}$

Bagian 2.5 ketentuan 12.1 KUHP Australia juga secara eksplisit menyatakan, bahwa semua ketentuan yang berlaku kepada individu juga berlaku kepada korporasi dengan perubahan-perubahan bila diperlukan. Korporasi juga dapat dipertanggungjawabkan secara pidana atas tindak pidana yang dilakukan, termasuk menjatuhkan sanksi pidana penjara kepada pengurusnya. ${ }^{36}$

\footnotetext{
${ }^{35}$ Joanna Kyriakakis, "Australian Prosecution Of Corporations For International Crimes”, Journal of International Criminal Justice, 2007, hlm. 814.

${ }^{36}$ Jennifer Hill, "Corporate Criminal Liability In Australia: an Evolving Corporate Governance Technique?”, Journal of Business Law, 2003, hlm. 16.
} 
Australia juga menerapkan prinsip jurisdiksi universal terhadap kejahatan terhadap kemanusiaan, kejahatan perang, dan genosida baik yang dilakukan oleh individu maupun oleh korporasi. Prinsip ini menyatakan bahwa setiap orang, tanpa memandang kewarganegaraannya atau tempat tinggalnya, akan diadili di Australia bila melakukan tiga kejahatan tersebut di manapun tempatnya. Prinsip ini juga diterapkan oleh Kanada, Belanda dan Inggris. ${ }^{37}$ Bila korporasi melakukan kejahatan terhadap kemanusiaan, kejahatan perang, dan genosida di luar Australia, negara ini berhak mengadili pelakunya.

Contoh kasus korporasi (MNC) Australia yang terlibat dalam pelanggaran HAM berat adalah keterlibatan perusahaan tambang Anvil Australia yang terlibat dalam upaya memberantas pemberontakan yang dilakukan angkatan bersenjata DRC di kota Kilwa, 50 kilometer dari perusahaan Dikulushi. 14 Oktober 2004 sekelompok kecil pemberontak bersenjata menduduki Kilwa dan mengklaim diri mereka sebagai gerakan pembebasan Katangan, yang mendapat dukungan luas dari politisi dan tentara Katanga yang ingin memisahkan diri. Kelompok tersebut kemudian mengadakan pertemuan publik dan meminta dukungan masyarakat lokal, mengambil alih tempat-tempat strategis termasuk kantor polisi, gudang penyimpanan senjata serta mengambilnya, dan kemudian bergerak menuju jantung kota. $^{38}$

Sebagai respon terhadap gerakan tersebut, serangan tandingan dilakukan oleh satu brigade angkatan bersenjata dengan menggunakan kendaraan Anvil. Truk dan pesawat Anvil digunakan untuk membawa para tentara menuju kota. Laporan MONUC dan Kelompok pemerhati HAM menemukan bahwa angkatan militer melakukan pembunuhan terhadap pemberontak dan penduduk sipil, pemerkosaan, perampokan pencurian harta dan kekayaan penduduk sipil, penangkapan dan penahanan secara paksa. Beberapa orang yang ditahan dihilangkan secara paksa dan dibunuh. Sebanyak 73 orang meninggal dalam serangan balik tersebut dengan rincian 28 orang dibunuh di tempat, sisanya dibunuh dengan cara disuruh berlutut di samping kuburan. Atas kejadian tersebut, pemerintah Australia kemudian mengadakan penyidikan dan akhirnya diputuskan bahwa tiga mantan pejabat senior Anvil dijadikan sebagai terdakwa karena terlibat dalam pembunuhan tersebut. ${ }^{39}$

\footnotetext{
${ }^{37}$ Ibid., hlm. 819.

${ }^{38}$ Ibid., hlm. 812.

${ }^{39}$ Ibid., hlm. 813-814.
} 


\section{Konteks Indonesia}

Di Indonesia undang-undang Pengadilan HAM tidak mengakui korporasi sebagai subjek delik, sehingga kalaupun korporasi melakukan pelanggaran HAM yang berat, maka eksistensi undang-undang tersebut tidak dapat digunakan. Namun demikian, ketiadaan pengaturan korporasi sebagai subjek delik tidak kemudian menutup kemungkinan penerapan pertanggungjawaban pidana korporasi dalam pelanggaran HAM yang berat. Justifikasi teoritis perlunya korporasi dipertanggungjawabkan secara pidana dalam pelanggaran HAM yang berat dalam sistem hukum pidana Indonesia setidaknya didasarkan pada dua alasan. Pertama, dampak negatif pelanggaran hukum oleh korporasi begitu kompleks, tidak hanya aspek hukum saja tapi juga aspek ekonomi, sosial, politik, dan budaya.

Kedua, seriusitas korban pelanggaran HAM yang berat oleh korporasi tidak kalah dibandingkan pelakunya manusia, bahkan dalam beberapa kasus terutama terkait dengan pencemaran lingkungan hidup, kondisi korban sangat mengenaskan. Ketiga, motif korporasi melakukan pelanggaran HAM yang berat lebih kompleks dibandingkan dengan motif individu. Hal ini karena umumnya, terdapat motif ekonomi yang selalu menyertai korporasi ketika melakukan pelanggaran HAM yang berat di samping motif yang lain.

Ketika korporasi diakui sebagai subjek delik dalam pelanggaran HAM yang berat, paling tidak terdapat tiga implikasi hukum yang perlu diperhatikan, yakni perumusan tindak pidana, pertanggungjawaban pidana, dan sanksi pidana. Hal ini karena prinsip-prinsip dasar terkait ketiga hal tersebut dalam sistem hukum pidana Indonesia masih mengacu pada subjek delik berupa manusia, dalam arti perumusan tindak pidana, pertanggungjawaban pidana, dan sanksi pidana lebih dominan mengarah pada subjek delik manusia.

Terkait perumusan tindak pidana yang dilakukan korporasi dalam pelanggaran HAM yang berat, ditolak pemikiran yang menyatakan bahwa korporasi tidak dapat membunuh, menculik, kerja paksa, melakukan pembersihan etnis, dan sebagainya yang selama ini umumnya dianggap hanya dapat dilakukan oleh manusia. Hal ini karena terbukti dalam dua kasus di atas, korporasi ternyata dalam melakukan tindakan pembunuhan walaupun tidak dilakukan secara langsung olehnya, tapi oleh pejabat senior atau perwakilannya. Selain itu, perumusan tindak pidana korporasi perlu diadakan rekonstruksi terutama terkait dengan delik penyertaan (turut serta). 
Teori tentang turut serta pada umumnya menyatakan bahwa yang dimaksud turut serta (mede pleger) adalah apabila perbuatan masing-masing peserta memuat semua anasir-anasir perbuatan pidana yang bersangkutan. ${ }^{40}$ Moeljatno mengatakan bahwa mede pleger adalah setidak-tidaknya mereka itu semua melakukan unsur perbuatan pidana, dan ini tidak berarti bahwa masing-masing harus melakukan bahkan tentang apa yang dilakukan peserta/tak mungkin dilakukan karena hal ini tergantung pada masing-masing keadaan. Yang perlu ditekankan di sini adalah dalam mede pleger terjadi kerjasama yang erat antara mereka pada waktu melakukan perbuatan pidana. $^{41}$

Berdasarkan konsepsi teoritis tersebut, terdapat ciri tiga penting mede pleger yang membedakannya dengan bentuk penyertaan yang lain. Pertama, pelaksanaan perbuatan pidana melibatkan dua orang atau lebih. Kedua, semua yang terlibat, benar-benar melakukan kerja sama secara fisik (saling membantu) dalam pelaksanaan perbuatan pidana yang terjadi. Ketiga, terjadinya kerja sama fisik bukan karena kebetulan, tetapi memang telah merupakan kesepakatan yang telah direncanakan bersama sebelumnya.

Bila konsep turut serta tersebut diterapkan kepada korporasi, syarat terjadinya kerjasama secara fisik sulit terpenuhi, karena umumnya korporasi tidak melakukan kejahatan secara langsung tapi melalui agen atau perwakilannya atau dilakukan langsung oleh partner kerjanya. Oleh karena itu, konsep turut serta dalam Pasal 55 KUHP perlu direkonstruksi bila diterapkan kepada korporasi, dalam artian agar korporasi terbukti melakukan delik penyertaan dalam pelanggaran HAM yang berat, maka terjadinya kerjasama secara fisik tidak mutlak diperlukan, tapi cukup apabila antara korporasi dan orang lain atau entitas hukum yang lain telah ada pertemuan dan perencanaan yang matang untuk terjadinya tindak pidana, tanpa harus mensyaratkan bahwa korporasi melalui agennya melakukan pelanggaran HAM yang berat secara langsung.

Dalam kaitan dengan siapa yang harus bertanggung jawab atas tindak pidana agen dari suatu korporasi, harus ada ketentuan limitatif yang berbeda dengan ketentuan perundang-undangan pidana yang selama ini ada jika korporasi melakukan suatu tindak pidana. Dalam doktrin dikenal tiga pihak yang dapat bertanggung jawab, yakni korporasi sendiri, pengurus korporsi, atau korporasi dan

\footnotetext{
${ }^{40}$ Utrecht, Hukum Pidana I, Penerbitan Universitas, Bandung, 1960, hlm. 32-33.

${ }^{41}$ Moeljatno, Hukum Pidana Delik-delik Percobaan Delik-delik Penyertaan, Bina Aksara, Jakarta, 1983, hlm. 113.
} 
pengurusnya. Untuk pelanggaran HAM yang berat yang dilakukan korporasi, hanya korporasi saja yang dapat dimintai pertanggungjawaban secara pidana.

Mengapa demikian? V.S. Khanna mengatakan, paling tidak ada tiga alasan yang dapat dikemukakan. Pertama, para pengurus tidak memiliki banyak aset jika harus bertanggung jawab atas tindak pidana yang dilakukan oleh korporasi, jika sanksi pidana denda dijatuhkan padanya. Oleh karena itu, masalah ini bisa diatasi dengan menyatakan bahwa satu-satunya pihak yang harus bertanggung jawab atas tindak pidana yang dilakukan oleh korporasi adalah korporasi itu sendiri. Kedua, hal itu akan memaksa korporasi untuk memonitor dan mencegah para agen melakukan tindak pidana, karena jika itu dilakukan, biaya yang harus ditanggung oleh korporasi sangat besar. Ketiga, alasan untuk mempertanggungjawabkan korporasi adalah ia melakukan tindak pidana berdasarkan prinsip rasionalitas. Sementara, para agen melakukan tindak pidana tidak lain hanya sebagai "perantara" saja dari suatu korporasi. ${ }^{42}$

Perubahan lain berkaitan dengan sanksi pidana. Apabila dalam undang-undang pengadilan HAM ada tiga bentuk sanksi pidana yang dapat dijatuhkan kepada pelaku pelangaran HAM yang berat, yakni pidana mati, pidana seumur hidup dan pidana penjara, maka harus ada penambahan bentuk sanksi di dalamnya. Hemat penulis, terdapat beberapa bentuk sanksi khusus bagi korporasi jika melakukan pelanggaran HAM yang berat, yaitu pidana denda, perampasan aset korporasi, dan perbaikan akibat tindak pidana, dan pemberian restitutsi kepada korban atau keluarganya.

Bentuk sanksi pidana denda ini diterapkan mengingat korporasi itu memiliki persona yang dapat diidentifikasi, di mana kehadirannya di dalam suatu masyarakat, sesungguhnya terpisah sama sekali dari pemilik, manager dan pekerja. ${ }^{43}$ Di samping itu, ketika melakukan suatu aktivitas, termasuk melakukan tindak pidana, korporasi berpikir (melalui agen) rasional yang menimbang antara untung dan rugi. ${ }^{44}$ Ketika suatu tindak pidana yang dilakukan ternyata mendatangkan keuntungan yang lebih besar dibandingkan dengan kerugian yang harus ditanggung, maka ia akan melakukan tindak pidana termasuk juga pelanggaran HAM yang berat.

\footnotetext{
${ }^{42}$ V.S Khanna, “Corporate Liability Standards: When Should Corporate be Held Criminallly Liable?”, American Criminal Law Review, 2000, hlm. 1243-1245.

${ }^{43}$ Lawrence Friedman, "In Defence of Corporate Crimial Liability", Harvard Journal of Law and Public Policy, 2000, hlm. 847.

${ }^{44}$ Dan M. Khan, “Social Influence, Social Meaning, and Deterrence”, Virginia Law Review, Vol 1997, hlm. 349.
} 
Dalam kaitannya dengan teori pemidanaan, teori pencegahan (deterrence) lebih tepat diterapkan kepada korporasi. Asumsi teori ini adalah manusia, begitu juga korporasi, merupakan entitas rasional yang ketika akan melakukan tindak pidana akan menimbang antara keuntungan yang akan didapatkan dan kerugian yang akan ditanggung. Jika ternyata, keuntungan yang akan didapat lebih besar dari kerugian yang harus ditanggung, baik manusia maupun korporasi akan melakukan kejahatan. Konsekuensinya, sanksi pidana harus lebih berat dari seriusitas tindak pidana yang dilakukan. ${ }^{45}$ Karena dengan hal itulah, manusia dan korporasi tidak melakukan tindak pidana. Perumusan ancaman sanksi pidana denda tidak dirumuskan secara eksplisit jumlah denda yang wajib dibayar oleh korporasi, tapi cukup dengan mengkalilipatkan jumlah tersebut disesuaikan dengan keuntungan yang diperoleh korporasi dan biaya penegakan hukum. ${ }^{46}$ Bilamana korporasi memperoleh keuntungan sebesar Rp. 100.000.000.000,00 maka denda yang dijatuhkan minimal Rp. 200.000.000.000,00 dan maksimal Rp. 400.000.000.000,00.

Dalam kaitan dengan pelanggaran HAM yang berat oleh korporasi, penjatuhan sanksi pidana denda harus lebih berat dari seriusitas tindak pidana yang dilakukan. Karena hanya dengan cara inilah, korporasi akan berpikir dua kali untuk melakukan pelanggaran HAM yang berat. Namun demikian, jika sanksi pidana tidak mampu dibayar oleh korporasi, maka sanksi lain yang dapat dijatuhkan adalah dengan merampas seluruh aset yang dimiliki oleh korporasi. Selain perampasan aset, sanksi lain yang dapat dijatuhkan adalah dengan mewajibakan korporasi memperbaiki semua akibat dari pelanggaran HAM yang berat yang dilakukan bila berkaitan dengan pencemaran lingkungan hidup. Pemberian restitusi adalah untuk meringankan beban korban atau keluarganya seandainya korban meninggal dunia.

\section{Penutup}

Berdasarkan pembahasan di atas, terdapat tiga kesimpulan dalam penelitian tentang pertanggungjawaban pidana korporasi dalam pelanggaran HAM yang berat. Pertama, paling tidak terdapat empat alasan perlunya korporasi dipertanggungjawabkan secara pidana dalam pelanggaran HAM yang berat, yaitu;

\footnotetext{
${ }^{45}$ Untuk mengetahui sanksi pidana bagi korporasi, baca Gilbert Geis dan Joseph F. Dimento,” Empirical Evidence and The Legal Doctrin of Corporate Criminal Liability", American Journal of Criminal Law, 2002, hlm. 371-373.

${ }^{46}$ Euston Quah dan William Neilson, Law and Economics Development: Cases and Materials from Southeast Asia, First Edition, Longman Singapore Publishers, Singapore, 1993, hlm. 1237-1238.
} 
negara-negara tidak bersedia atau tidak memiliki kekuatan untuk menjatuhkan sanksi pidana kepada korporasi disebabkan adanya rasa takut negara tersebut akan menanggung konsekuensi ekonomi yang bersifat negatif; kejahatan korporasi di bidang bisnis dan lingkungan hidup menimbulkan efek negatif yang berkepanjangan dan luar biasa; korporasi seringkali memelihara budaya kerja yang mengarah pada terjadinya pelanggaran HAM yang berat; dan seringkali korporasi terlibat langsung dalam pelanggaran HAM yang berat yang serius dan sistemasik.

Kedua, Kanada mengakui korporasi sebagai subjek delik dalam pelanggaran HAM yang berat sebagaimana diatur dalam the Canadian Crimes Against Humanity and War Crimes Act 2000. Undang-undang ini di samping diberlakukan secara surut juga mengatur pengertian "membantu" dan "turut serta" serta unsur objektif (actus reus/guilty act) dan unsur subjektif (guilty mind/mens rea) kejahatan terhadap kemanusiaan dan kejahatan perang. Pengakuan Kanada terhadap korporasi sebagai subjek delik dibuktikan dengan putusan pengadilan yang menyatakan bahwa perusahaan Unocal terbukti melakukan kejahatan terhadap kemanusiaan dalam kasus yang terjadi di Myanmar. Sedangkan Australia mengakui korporasi sebagai subjek delik dalam kejahatan terhadap kemanusiaan, genosida dan kejahatan perang. Hal ini dibuktikan dengan dijadikannya tiga mantan pejabat senior perusahaan Anvil dalam kasus kejahatan terhadap kemanusiaan yang dilakukan tentara Katangan.

Ketiga, bila korporasi dipertanggungjawabkan dalam pelanggaran HAM yang berat di Indonesia, maka formulasi delik penyertaan dalam Pasal 55 KUHP seharusnya direkonstruksi, karena tidak cocok untuk korporasi. Sedangkan yang dipertanggungjawabkan secara pidana haruslah korporasi sendiri, bukan pengurusnya. Adapun bentuk-bentuk sanksi pidana yang dapat dijatuhkan kepada korporasi meliputi pidana denda, perampasan aset korporasi, kewajiban korporasi untuk memulihkan akibat tindak pidana, dan pemberian restitusi kepada korban atau keluarganya. Khusus mengenai formulasi pidana denda, seyogyanya mengikuti prinsip-prinsip dasar dalam analisis ekonomi atas hukum pidana (economic analysis of criminal law).

\section{Daftar Pustaka}

Ali, Mahrus, Kejahatan Korporasi, Arti Bumi Intaran, Yogyakarta, 2008.

B. Miles, Matthew dan A. Michael Huberman, Analisis Data Kualitatif, tanpa Penerbit, tt. 
Bookman, Zachary, "Convergences and Omissions in Reporting Corporate and White Collar Crime, DePaul Business E Commercial Law Journal, 2008.

Clapham, Andrew, "Extending International Criminal Law beyond the Individual to Corporations and Armed Opposition Groups", Journal of International Criminal Justice, 2008.

Clarkson, C.M.V., Understanding Criminal Law, Second Edition, Sweet \& Maxwell, London, 1998.

Clough, Jonathan, "Punishing the Parent: Corporate Criminal Complicity in Human Rights Abuses" Brooklyn Journal of International Law, 2008.

Colvin, Eric, "Corporate Personality and Criminal Liability", Criminal Law Forum, 1995.

Cory Wanless, W., “Corporate Liability for International Crimes under Canada's Crimes against Humanity and War Crimes Act", Journal of International Criminal Justice, 2009.

Friedman, Lawrence, "In Defence of Corporate Crimial Liability", Harvard Journal of Law and Public Policy, 2000.

G.A. Tzeutschler, Gregory, "Corporate Violator: the Alien Tort Liability of Transnational Corporations for Human Rights Abuses Abroad", Columbia Human Rights Law Review, 1999.

H. Bucy, Pamela, “Trends in Corporate Criminal Prosecutions”, American Criminal Law Review, 2007.

Hanafi, Strict Liability dan Vicarious Liability dalam Hukum Pidana, Lembaga Penelitian, Universitas Islam Indonesia, Yogyakarta, 1997.

Hatrik, Hamzah, Asas Pertanggunggjawaban Korporasi Dalam Hukum Pidana (Strick Liability dan Vicarious Liability), PT Raja Grafindo Persada, Jakarta, 1996.

Heaton, Russel, Criminal Law Textbook, Oxford University Press, London, 2006.

Henry J. Steiner, Cf., “Organizational Irrationality and Corporate Human Rights Violations", Harvard Law Review, 2009.

Hill, Jennifer, "Corporate Criminal Liability In Australia: an Evolving Corporate Governance Technique?", Journal of Business Law, 2003.

I. Blumberg, Phillip, “Asserting Human Rights against Multinational Corporations under United States Law: Conceptual and Procedural Problems", American Journal of Comparative Law, 2002.

Khanna, V.S., "Corporate Liability Standards: When Should Corporation Be Criminality Liabel?", American Criminal Law Review, 2000.

Kyriakakis, Joanna, “Australian Prosecution of Corporations for International Crimes", Journal of International Criminal Justice, 2007.

M. Khan, Dan, "Social Influence, Social Meaning, and Deterrence”, Virginia Law Review, Vol. 1997, Priyanto, Dwidja, Kebijakan Legislatif tentang Sistem Pertanggungjawaban Korporasi di Indonesia, CV. Utomo, Bandung, 2004. 
Mahmud Marzuki, Peter, Penelitian Hukum, Cetk. Kedua, Prenada Media, Jakarta, 2006.

Orland, Leonard, "The Transformation of Corporate Criminal Law", Brooklyn Journal of Corporate, Finansial \& Commercial Law, 2006.

Quah, Euston dan William Neilson, Law and Economics Development: Cases and Materials from Southeast Asia, First Edition, Longman Singapore Publishers, Singapore, 1993.

Reksodiputro, Mardjono, “Pertanggungjawaban Pidana Korporasi Dalam Tindak Pidana Korporasi", makalah disampaikan pada Seminar Nasional Kejahatan Korporasi, FH UNDIP, Semarang, 23-24 Novemser 1989.

R LaFave, Wayne \& Austin W. Scott Jr, Criminal Law, West Publishing co, 1982.

Stephens, Beth, “The Amorality of Profit: Transnational Corporations and Human Rights", Berkeley Journal of International Law, 2002.

Sutan, Remy Sjahdeini, Pertanggung Jawaban Pidana Korporasi, Grafiti Pers, Jakarta, 2006.

Szott Moohr, Geraldine, "On The Prospects Of Deterring Corporate Crime”, Journal of Business \& Technology Law, 2007.

Titus Reid, Sue, Criminal Law, Third Edition, Prentice Hall, New Jersey, 1995.

UdwadiaHYPERLINK "http://web2.westlaw.com/Find/Default.w1?DB= PROFILER \%2DWLD\&DocName $=0360606001 \&$ Find Type $=$ h\&AP $=\& m l a c=$ FY\&rs=WLW9.10\&ifm $=$ NotSet\&fn= top\&sv $=$ Split\&mt $=$ WorldJournals \& utid $=2 \& v r=2.0 \& p b c=942 B B 175 "$, Shanaira, "Corporate Responsibility for International Human Rights Violations", Southern California Interdisciplinary Law Journal, 2004.

Utrecht, Hukum Pidana I, Penerbitan Universitas, Bandung, 1960.

Weissmann, Andrew dan David Newman, "Rethinking Criminal Corporate Liability", Indiana Law Journal, 2007.

Weigend, Thomas, "Societas Delinquere Non Potest? A German Perspective", Journal of International Criminal Justice, 2008.

Wigjnosoebroto, Soetandyo, Hukum, Paradigma, Metode dan Dinamika Masalahnya, HuMa, Jakarta, 2002.

Z. Stern, Yedidia, "Corporate Criminal Personal Liability - Who Is The Corporation?", Journal of Corporation Law, 1987. 